\title{
THE MINOAN SANTORINI ERUPTION AND TSUNAMI DEPOSITS IN PALAIKASTRO (CRETE): DATING BY GEOLOGY, ARCHAEOLOGY, ${ }^{14} \mathrm{C}$, AND EGYPTIAN CHRONOLOGY
}

\author{
Hendrik J Bruins ${ }^{1} \cdot J^{\prime}$ hannes van der Plicht $^{2}$ • J Alexander MacGillivray ${ }^{3}$
}

\begin{abstract}
Deposits from the Minoan Santorini (Thera) eruption in the eastern Mediterranean region constitute the most important regional stratigraphic marker in the chronological perplexity of the 2nd millennium BCE. Extensive tsunami deposits were discovered in Crete at the Minoan archaeological site of Palaikastro, containing reworked volcanic Santorini ash. Hence, airborne deposition of volcanic ash, probably during the 1st (Plinian) eruption phase, preceded the tsunami, which was apparently generated during the 3rd or 4th phase of the eruption, based on evidence from Thera. Average radiocarbon dates (uncalibrated) of animal bones in the Palaikastro tsunami deposits along the coast ( $3350 \pm 25 \mathrm{BP}$ ) and at the inland archaeological site (3352 $\pm 23 \mathrm{BP}$ ) are astoundingly similar to the average ${ }^{14} \mathrm{C}$ date for the Minoan Santorini eruption at Akrotiri on Thera $(3350 \pm 10 \mathrm{BP})$. The wiggle-matched ${ }^{14} \mathrm{C}$ date of the eruption in calendar years is $1627-1600$ cal BCE. Late Minoan IA pottery is the youngest element in the Palaikastro tsunami deposits, fitting with the LM IA archaeological date for the Santorini eruption, conventionally linked at $~ 1500$ BCE with Dynasty XVIII of the historical Egyptian chronology. The reasons for the discrepancy of 100-150 yr between ${ }^{14} \mathrm{C}$ dating and Egyptian chronology for part of the 2nd millennium BCE are unknown. ${ }^{14} \mathrm{C}$ dates from Tell el-Dabca in the eastern Nile Delta show that the ${ }^{14} \mathrm{C}$ age of the Santorini eruption matches with ${ }^{14} \mathrm{C}$ results from 18th Dynasty strata C3 and C2, thereby confirming grosso modo the conventional archaeo-historical correlations between the Aegean and Egypt. We propose that a dual dating system is used in parallel: (1) archaeological materialcultural correlations linked to Egyptian chronology; (2) ${ }^{14} \mathrm{C}$ dating. Mixing of dates from the 2 systems may lead to erroneous archaeological and historical correlations. A “calibration curve" should be established between Egyptian chronology and ${ }^{14} \mathrm{C}$ dating for the 2nd millennium BCE, which may also assist to resolve the cause of the discrepancy.
\end{abstract}

\section{INTRODUCTION}

The Santorini or Thera Volcano is situated in the eastern Mediterranean Sea, about $120 \mathrm{~km}$ north of Crete (Figure 1). Thera is the Greek name for the largest of the 3 Santorini islands that surround the caldera; another 2 islands have formed later inside the caldera. The catastrophic eruption during the Late Minoan IA period (Doumas 1983), in the middle part of the 2nd millennium BCE (Table 1), is of critical importance as a regional stratigraphic marker in view of the problems between radiocarbon dating and archaeo-historical dating. A difference of about 100-150 yr exists between conventional archaeo-historical dating and ${ }^{14} \mathrm{C}$ dating concerning the time of the Minoan Santorini eruption (Manning 1999; Bietak 2003; Bruins and van der Plicht 2003; Wiener 2003, 2007; Manning et al. 2006; Bietak and Höflmayer 2007; Warren 2007).

Therefore, the presence in archaeological stratigraphic sequences of volcanic tephra or tsunami deposits related to the latter eruption is very important to investigate this vexing dating problem. Santorini tephra reached various distal places in the eastern Mediterranean region from the Nile Delta to the Black Sea, as fine volcanic dust (ash) and/or floating pumice of pebble or cobble size (Doumas and Papazoglou 1980; Keller 1980; McCoy 1980; Doumas 1983; Druitt et al. 1999; Friedrich 2000; McCoy and Heiken 2000a). We focus in this article on the Minoan site of Palaikastro in northeastern Crete, where volcanic Santorini ash occurs within the archaeological stratigraphy

\footnotetext{
${ }^{1}$ Ben-Gurion University of the Negev, Jacob Blaustein Institutes for Desert Research, Sede Boker Campus \& Dept. of Bible, Archaeology and Ancient Near Eastern Studies, Beer Sheva, Israel. Corresponding author. Email: hjbruins@bgu.ac.il.

${ }^{2}$ University of Groningen, Centre for Isotope Research, Nijenborgh, Groningen, The Netherlands \& Leiden University, Faculty of Archaeology, Leiden, The Netherlands.

${ }^{3}$ British School of Archaeology in Athens, Odos Souedias 52, 10676 Athens, Greece.
}

(C) 2009 by the Arizona Board of Regents on behalf of the University of Arizona

Proceedings of the 5th International ${ }^{14} \mathrm{C}$ and Archaeology Symposium, edited by Irka Hajdas et al.

RADIOCARBON, Vol 51, Nr 2, 2009, p 397-411 
(MacGillivray et al. 1991, 1998). Extensive tsunami deposits were discovered here (Bruins et al. 2008), dated to the Santorini eruption based on geological, archaeological, and ${ }^{14} \mathrm{C}$ evidence.

Table 1 Simplified conventional scheme of archaeological material-cultural relationships between Thera, Crete and Egypt in the 2nd millennium BCE, forming the basis of archaeo-historical dating linked to the Egyptian historical chronology. ${ }^{\text {a }}$

\begin{tabular}{|c|c|c|c|}
\hline $\begin{array}{l}\text { Thera } \\
\text { (Santorini) }\end{array}$ & Crete & $\begin{array}{l}\text { Egypt } \\
\text { (Dynasties) }\end{array}$ & $\begin{array}{l}\text { Years BCE } \\
\text { (Egyptian chronology) }\end{array}$ \\
\hline Late Cycladic IIIB & Late Minoan III & XIX & 1295-1186 \\
\hline \multirow[t]{2}{*}{ Gap } & Late Minoan II & \multirow{3}{*}{ XVIII } & \multirow{3}{*}{ 1550/1539-1295 } \\
\hline & Late Minoan IB & & \\
\hline Eruption & \multirow{2}{*}{ Late Minoan IA } & & \\
\hline Late Cycladic IA & & & \multirow{2}{*}{ 1801/1759-1550/1539 } \\
\hline \multirow{2}{*}{ Middle Cycladic } & Middle Minoan III & $\begin{array}{l}\text { Hyksos XV/ } \\
\text { XIII-XIV }\end{array}$ & \\
\hline & Middle Minoan II & XII & 1979/1937-1801/1759 \\
\hline
\end{tabular}

a Archaeological correlations based on Doumas (1983:159), Bietak and Höflmayer (2007:18-9). The Egyptian dates for the dynasties show options for both a "high" and “low" chronology, as discussed by Kitchen (1987) and Ward (1992); see also Kitchen (1996), Krauss and Hornung (2006).

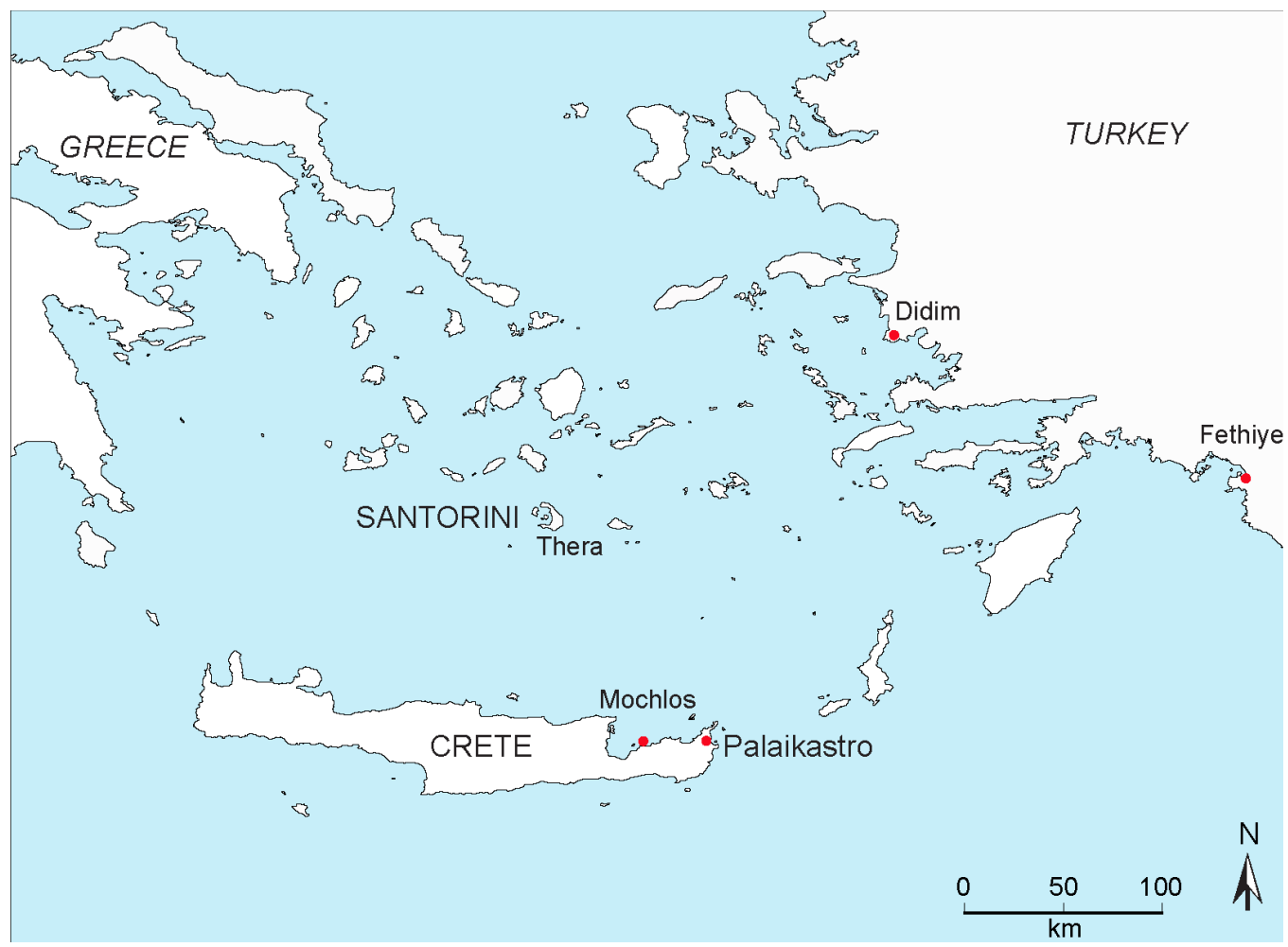

Figure 1 Location of the Santorini (Thera) Volcano and the archaeological sites of Palaikastro and Mochlos in NE Crete, where volcanic ash was found from the Minoan Santorini eruption. Tsunami deposits related to the latter eruption were discovered on Thera (McCoy and Heiken 2000b), along the Turkish coast in Didim and Fethiye (Minoura et al. 2000), and on Crete in Palaikastro (Bruins et al. 2008). 
The Minoan Santorini eruption has been upgraded to a Volcanic Explosivity Index (VEI) of about 7 (on a scale of 1 to 8), i.e. super-colossal. McCoy and Dunn (2002) made a reassessment of the distal volcanic ash amount. Sigurdsson et al. (2006) investigated the extent of pyroclastic flows from the Minoan eruption below the water level of the Mediterranean Sea around Santorini and concluded its volume to be $54.5 \mathrm{~km}^{3}$, or about $41 \mathrm{~km}^{3}$ dense rock equivalent (DRE). They calculated the total eruptive volume at $\sim 60 \mathrm{~km}^{3} \mathrm{DRE}$, which is nearly twice the previous assessment. Thus, the Minoan volcanic cataclysm approaches the size of the Tambora eruption ( $100 \mathrm{~km}^{3}$ DRE and VEI of 7), the largest volcanic event in the world during historical times, which occurred in Indonesia in 1815 (Sigurdsson and Carey 1989). The massive Krakatau eruption for comparison, which also took place in Indonesia (1883), had a DRE of $\sim 21 \mathrm{~km}^{3}$ and a VEI of 6.

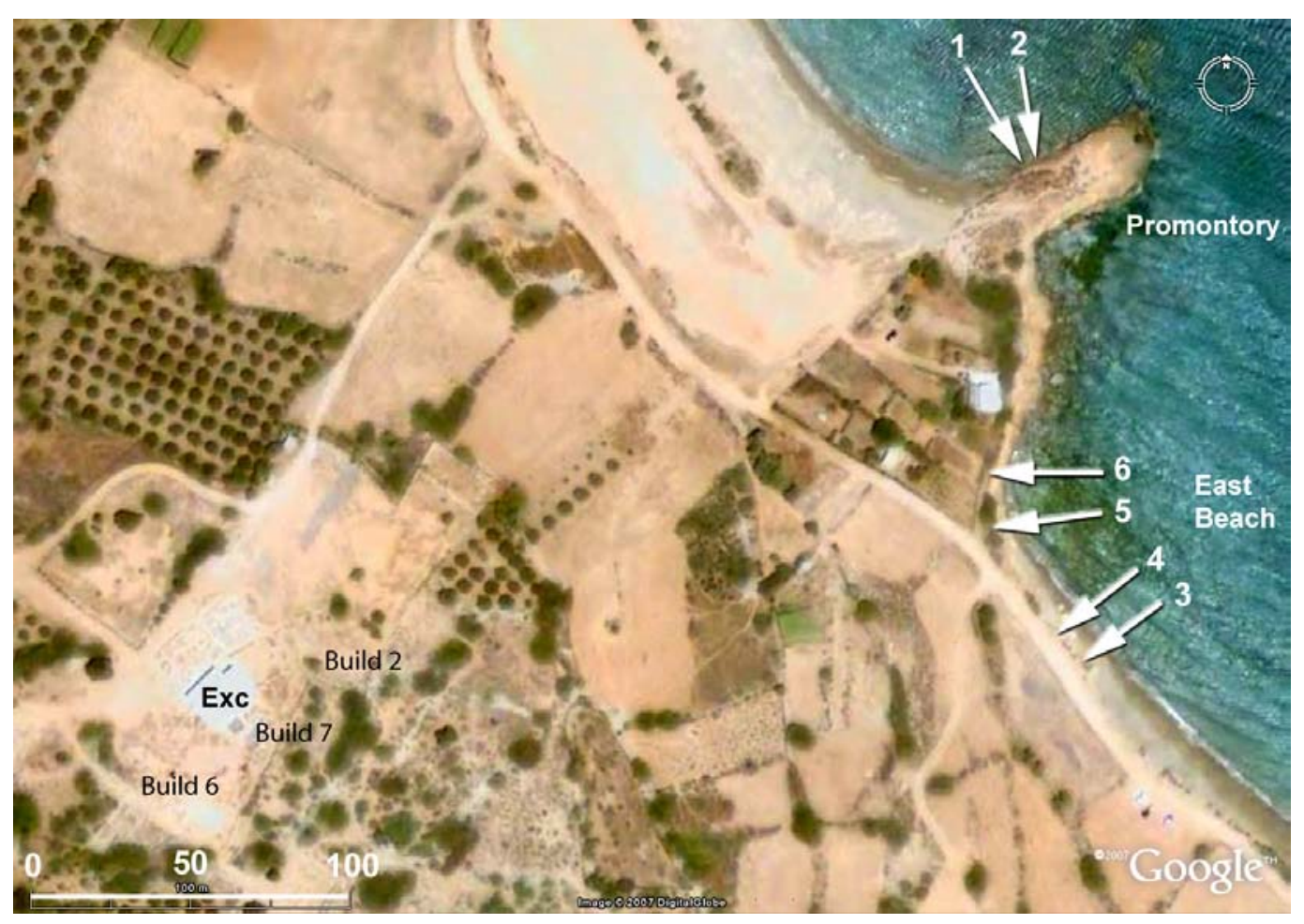

Figure 2 The area of Minoan Palaikastro, showing the present coastline with investigated field sections and the excavated part of the ancient town (left). Volcanic Santorini ash of the Minoan eruption was found in field section 2 and near Buildings 6 and 7. Source: Bruins et al. 2008:194.

Though Marinatos (1939) suggested that a tsunami generated by the Minoan Santorini eruption had probably impacted the coast of Crete, hardly any confirmation was found (Doumas 1983; Driessen and Macdonald 1997; Dominey-Howes 2004). However, Bruins et al. (2008) have recently discovered extensive tsunami evidence, dated to the time of the Santorini eruption, at the Minoan town of Palaikastro along the northeast coast of Crete (Figures 1-5). The term geoarchaeological tsunami deposit was introduced (Bruins et al. 2008), as both archaeological and geological components appear together (Figure 3-5). The criteria and evidence for the identification of tsunami signatures in these deposits at Palaikastro were treated in detail by Bruins et al. (2008). 


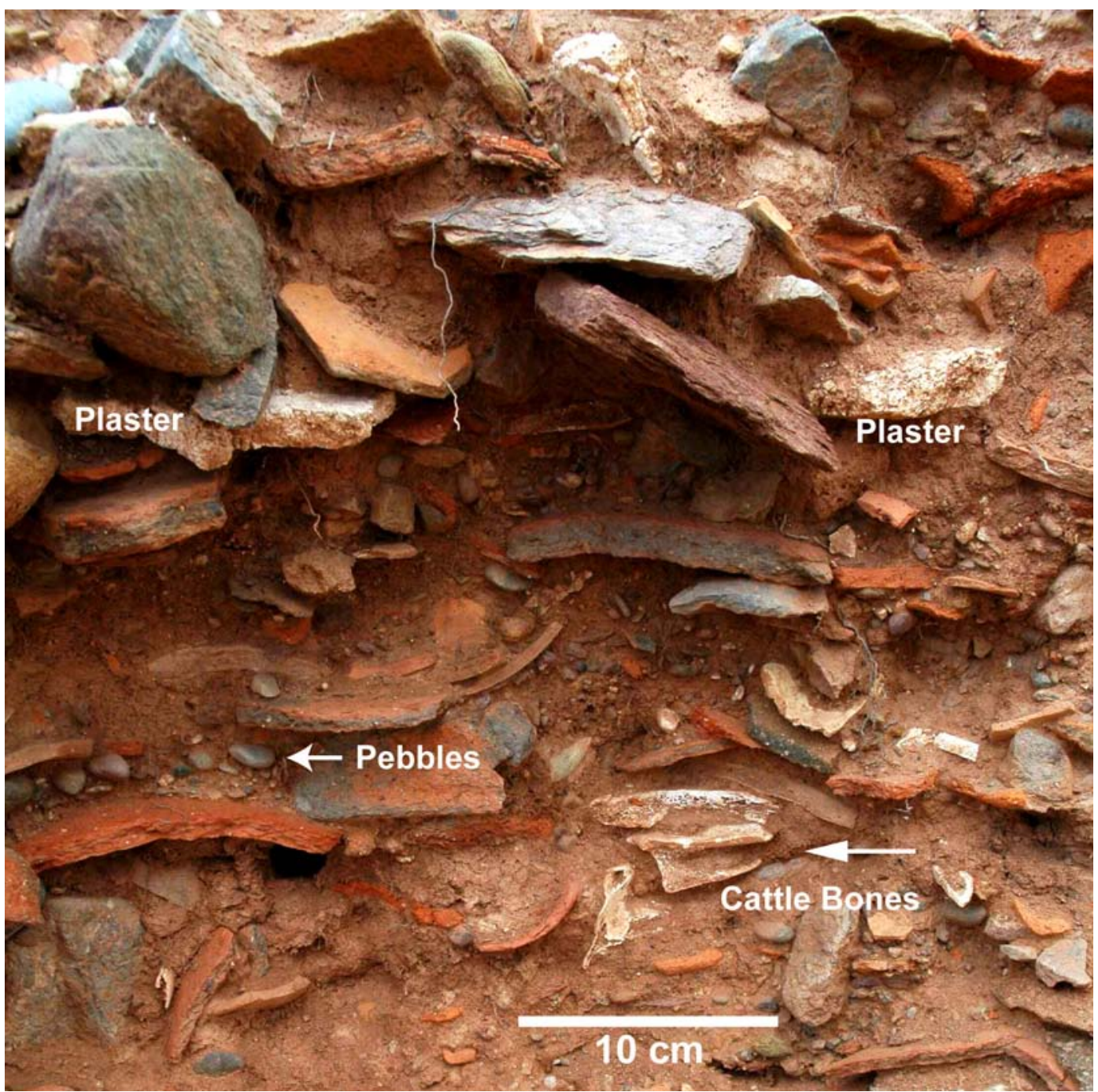

Figure 3 Geoarchaeological tsunami deposit at the Promontory (Figure 2, field section 1) in Palaikastro, showing multimodal chaotic deposits with imbrication (indicative of strong water flows) of stone slabs, wall plaster, ceramic sherds and cattle bones. Notice also the presence of rounded beach pebbles. The ${ }^{14} \mathrm{C}$ dates of the bones match very well with the ${ }^{14} \mathrm{C}$ age of the Minoan Santorini eruption (Tables 2, 3). Source: Bruins et al. 2008:198.

The geoarchaeological tsunami deposits at Palaikastro exhibit a threefold combination of features that are very important in the temporal evaluation of these layers in relation to the Santorini eruption and the material-cultural archaeological framework (Bruins et al. 2008). 1. Geological dating: airborne volcanic Santorini ash, reworked in water as a result of the tsunami, occurs at several locations in these deposits, both along the coast (Promontory) and in the excavated part of Palaikastro about $300 \mathrm{~m}$ inland. 2. Archaeological dating: pottery sherds in these deposits, as well as their stratigraphic position in the excavated parts of the Minoan town, enable archaeological age assessment (Table 1), based on ceramic styles and their position in the regional archaeo-historical framework, linked to the Egyptian chronology. 3. Radiocarbon dating: the presence of animal bones in these deposits enables ${ }^{14} \mathrm{C}$ dating. 
In this article, we focus on the dating of the geoarchaeological tsunami deposits at Palaikastro and we report the first ${ }^{14} \mathrm{C}$ measurements of animal bones from the excavated part of Palaikastro (Figure 2, Tables 2, 3). The significance and ramifications of the threefold dating-geological, archaeological, and ${ }^{14} \mathrm{C}$ —of these deposits, time parallel with the Santorini eruption, are evaluated and discussed in relation to regional archaeo-historical associations and Egyptian chronology.

Table $2{ }^{14} \mathrm{C}$ dates of animal bones and a marine shell found in tsunami deposits in Minoan Palaikastro. The first 3 dates are from the Promontory (Bruins et al. 2008), but the other 3 dates are from the excavated part of the ancient town, $300 \mathrm{~m}$ inland from the present coastline (Figure 2).

\begin{tabular}{|c|c|c|c|c|c|c|}
\hline Field sample & Material & Stratigraphy & Lab nr & $\begin{array}{l}{ }^{14} \mathrm{C} \text { age } \\
\text { (yr BP) }\end{array}$ & $\begin{array}{l}\delta^{13} \mathrm{C} \\
(\%)\end{array}$ & Note $^{\mathrm{a}}$ \\
\hline Promontory & Cattle bone & \multirow{2}{*}{$\begin{array}{l}\text { Section } 1 \text { in chaotic deposit } \\
\text { showing imbrication }\end{array}$} & GrA-30336 & $3310 \pm 35$ & -20.81 & \\
\hline Promontory & Cattle bone & & GrA-30339 & $3390 \pm 35$ & -18.71 & \\
\hline Promontory & $\begin{array}{l}\text { Marine shell } \\
\text { Patellidae } \\
\end{array}$ & $\begin{array}{l}\text { Section } 2 \text { in chaotic deposit } \\
\text { with Santorini ash }\end{array}$ & GrA-21607 & $3790 \pm 60$ & 2.48 & \\
\hline \multirow{3}{*}{$\begin{array}{l}\text { East of Building } 6 \\
\text { (zembil 2878) }\end{array}$} & \multirow{2}{*}{$\begin{array}{l}\text { Goat/sheep } \\
\text { bone, lower jaw }\end{array}$} & \multirow{3}{*}{$\begin{array}{l}\text { Large drain filled with stratified } \\
\text { Santorini ash (water-laid) and } \\
\text { mud }\end{array}$} & GrA-28991 & $3325 \pm 40$ & -20.20 & $\mathrm{D}$ \\
\hline & & & GrA-29041 & $3345 \pm 40$ & -20.14 & $\mathrm{D}$ \\
\hline & Tooth & & GrA-29042 & $3385 \pm 40$ & -20.13 & \\
\hline
\end{tabular}

${ }^{a} \mathrm{D}=$ duplicate measurement. All 5 bone dates (uncalibrated) are similar, overlapping with each other and, most important, with the average uncalibrated date (3350 \pm 10 BP, Bronk Ramsey et al. 2004) for the Santorini eruption. The shell date also matches with the latter date, as $\sim 400$ yr have to be deducted because of the marine reservoir effect.

Table 3 Comparison between geological, archaeological, and ${ }^{14} \mathrm{C}$ dating of the tsunami deposits at Palaikastro, in relation to ${ }^{14} \mathrm{C}$ dates of the Minoan Santorini eruption from Thera. The last column shows the conventional archaeo-historical date for the eruption, based on interregional cultural-material correlations linked to Egyptian chronology.

\begin{tabular}{|c|c|c|c|c|c|}
\hline $\begin{array}{l}\text { Location \& } \\
\text { object }\end{array}$ & $\begin{array}{l}\text { Relative } \\
\text { geological } \\
\text { dating }\end{array}$ & $\begin{array}{l}\text { Relative } \\
\text { archaeological } \\
\text { dating }\end{array}$ & $\begin{array}{l}\text { Average }{ }^{14} \mathrm{C} \\
\text { date BP } \\
\left({ }^{14} \mathrm{C} \text { timescale }\right)\end{array}$ & $\begin{array}{l}\text { Calibrated }{ }^{14} \mathrm{C} \text { date } \\
\text { BCE (IntCal04) } \\
\text { (calendar years) }\end{array}$ & $\begin{array}{l}\text { Archaeo-historical } \\
\text { date BCE based on } \\
\text { Egyptian chronology }\end{array}$ \\
\hline $\begin{array}{l}\text { Crete, Palai- } \\
\text { kastro tsunami } \\
\text { deposits at } \\
\text { Promontory }\end{array}$ & $\begin{array}{l}\text { Volcanic ash } \\
\text { from Minoan } \\
\text { Santorini } \\
\text { eruption }\end{array}$ & $\begin{array}{l}\text { Late Minoan } \\
\text { IA Ceramics }\end{array}$ & $3350 \pm 25$ & $\begin{array}{l}1732-1715(3.7 \%) \\
1692-1603(78.3 \%) \\
1587-1533(13.4 \%)\end{array}$ & \\
\hline $\begin{array}{l}\text { Crete, Palai- } \\
\text { kastro tsunami } \\
\text { deposits east of } \\
\text { Building } 6\end{array}$ & $\begin{array}{l}\text { Volcanic ash } \\
\text { from Minoan } \\
\text { Santorini } \\
\text { eruption }\end{array}$ & $\begin{array}{l}\text { Late Minoan } \\
\text { IA Ceramics }\end{array}$ & $3352 \pm 23$ & $\begin{array}{l}1732-1715 \quad(3.7 \%) \\
1692-1604(81.3 \%) \\
1584-1535(10.4 \%)\end{array}$ & $\begin{array}{l}\text { Dynasty XVIII } \\
\text { about } 1500\end{array}$ \\
\hline $\begin{array}{l}\text { Thera }{ }^{\mathrm{a}}, \mathrm{Ak}- \\
\text { rotiri destruc- } \\
\text { tion layer } \\
\text { Minoan San- } \\
\text { torini eruption }\end{array}$ & $\begin{array}{l}\text { Volcanic te- } \\
\text { phra from Mi- } \\
\text { noan Santorini } \\
\text { eruption }\end{array}$ & $\begin{array}{l}\text { Late Cycladic } \\
\text { IA \& Late Mi- } \\
\text { noan IA Ce- } \\
\text { ramics }\end{array}$ & $3350 \pm 10$ & 1685-1614 (95.4\%) & \\
\hline $\begin{array}{l}\text { Therab }{ }^{\mathrm{b}} \text {, olive } \\
\text { tree buried by } \\
\text { tephra }\end{array}$ & $\begin{array}{l}\text { Volcanic te- } \\
\text { phra from Mi- } \\
\text { noan Santorini } \\
\text { eruption }\end{array}$ & - & $\begin{array}{l}\text { Sequence of } \\
{ }^{14} \mathrm{C} \text { dates of } \\
\text { tree rings }\end{array}$ & $\begin{array}{l}1627-1600(95.4 \%) \\
\text { by wiggle-matching }\end{array}$ & \\
\hline
\end{tabular}

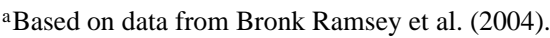

${ }^{\mathrm{b}}$ Based on data from Friedrich et al. (2006). 


\section{GEOLOGICAL DATING OF THE TSUNAMI DEPOSITS}

Volcanic ash appears at Palaikastro as distinct intraclasts in chaotic geoarchaeological tsunami deposits in field section 2 (Bruins et al. 2008) along the Promontory (Figures 2, 4, 5) and as discrete layers more inland within and near Buildings 6 and 7 (MacGillivray et al. 1991, 1998). These deposits are geologically dated to the Minoan Santorini eruption, because the embedded volcanic ash is proven to have the geochemical fingerprint of this eruption (Bruins et al. 2008). Measurements of major elements on single volcanic glass shards from different locations at Palaikastro were conducted by Jörg Keller (University of Freiburg) using electron probe micro-analysis (EPMA). Measurements of trace elements were attained by Andreas Klügel (University of Bremen) using laser ablation inductively coupled plasma mass spectrometry (LA-ICP-MS) (Bruins et al. 2008).

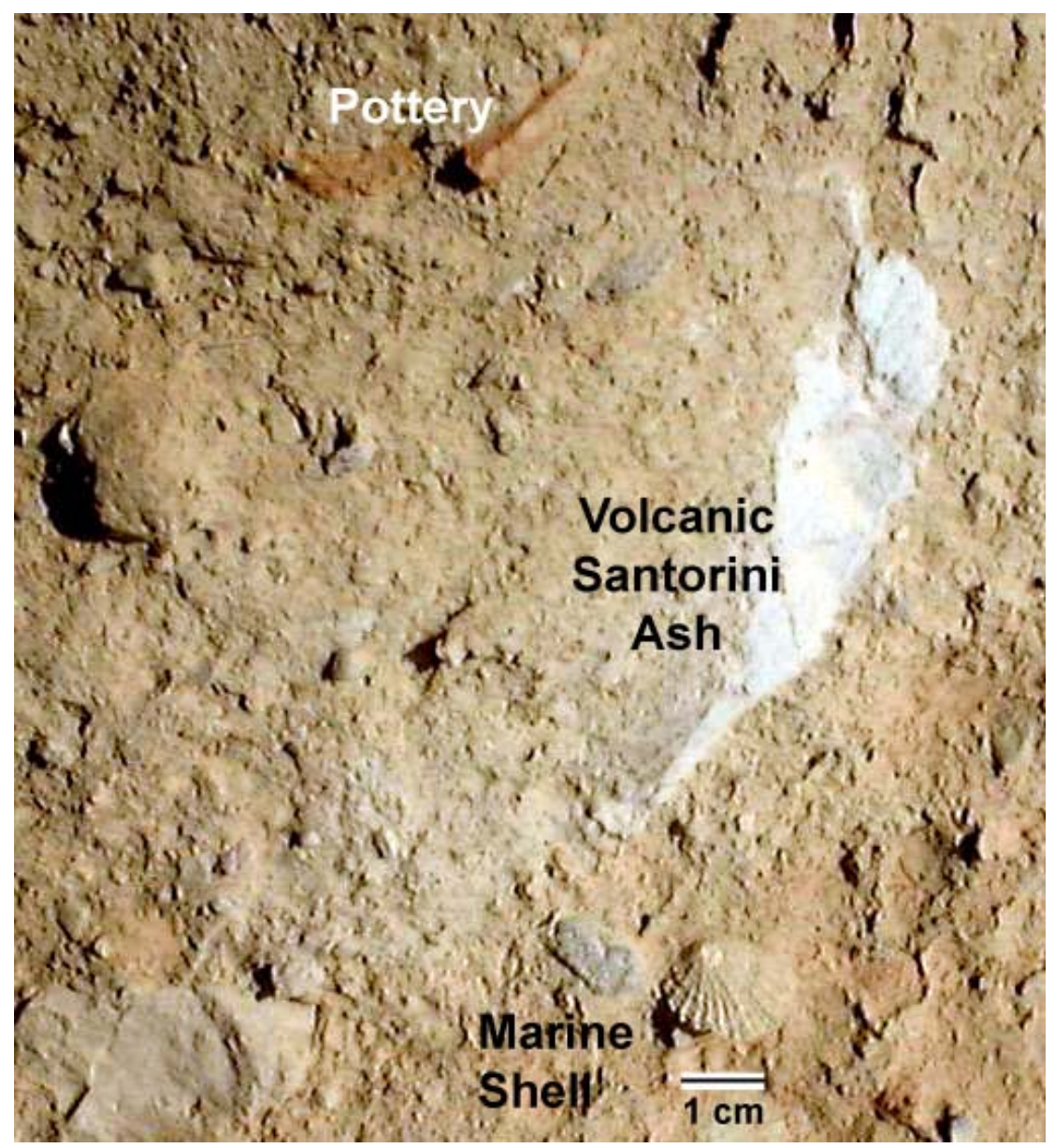

Figure 4 Volcanic Santorini ash, a marine Patellidae shell (having a ${ }^{14} \mathrm{C}$ date that fits the ${ }^{14} \mathrm{C}$ time of the Minoan Santorini eruption-Table 2), stones and pottery sherds in a multimodal tsunami deposit at the Promontory (Figure 2, field section 2). Bruins et al. 2008:199.

The volcanic ash was evidently reworked by the tsunami and redeposited with the other multimodal components of the non-sorted sediment (Figures 4, 5). Considering the eruption sequence at Santorini (Druitt et al. 1999; Friedrich 2000; McCoy and Heiken 2000a) and the presence of reworked 
volcanic ash in the tsunami deposits at Palaikastro, it can be concluded that airborne volcanic ash deposition over eastern Crete preceded the tsunami. The volcanic ash was most likely deposited at Palaikastro during the 1st eruption phase (Plinian) with winds blowing from Santorini to the southeast (Figure 1). The tsunami was apparently generated during the 3rd or 4th eruption phase, according to stratigraphic evidence of tsunami deposits at Thera (Druitt et al. 1999; McCoy and Heiken 2000b).

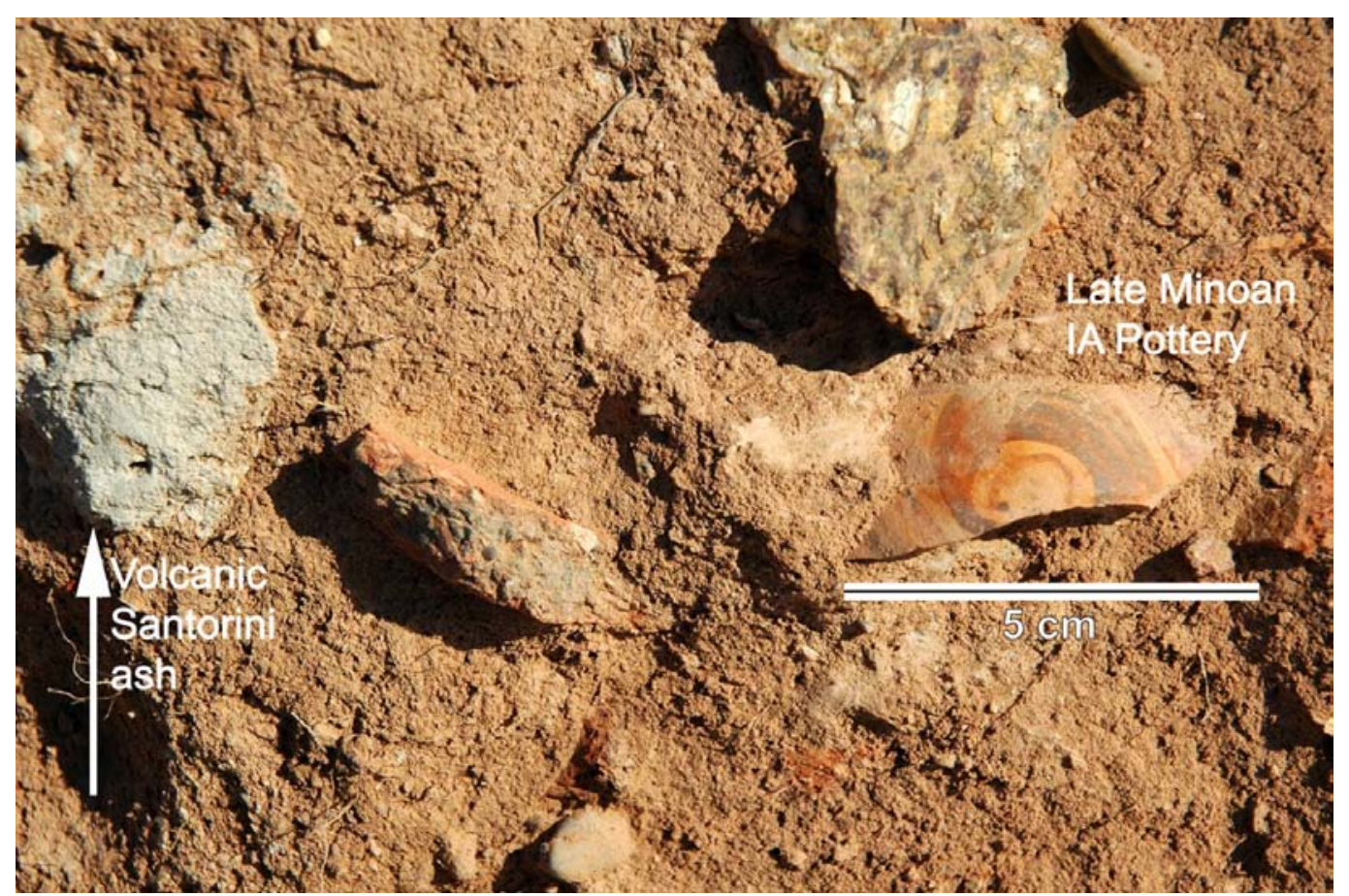

Figure 5 A diagnostic Late Minoan IA ceramic sherd in a chaotic multimodal tsunami deposit with intraclasts of volcanic Santorini ash in field section 2 at the Promontory. Source: Bruins et al. 2008:199.

Findings of discrete volcanic ash in eastern Crete are rare. Excavations at the archaeological sites (Figure 1) of Mochlos (Soles and Davaras 1990) and Palaikastro (MacGillivray et al. 1991, 1998) revealed volcanic ash in archaeological stratigraphic context. The spatial extent and thickness of the Minoan Santorini volcanic ash layer in Mediterranean deep-sea sediments indicate that eastern Crete was covered by an estimated $5 \mathrm{~cm}$ of volcanic tephra (Thorarinsson 1978; Watkins et al. 1978; McCoy 1980). Volcanic ash particles originating from the Minoan Santorini eruption have been found in soils of eastern Crete in a dispersed state and not as a discrete layer (Vitaliano and Vitaliano 1974; Betancourt et al. 1990).

It is obvious that the tsunami at Palaikastro could not have caused redeposition of discrete volcanic ash layers or discrete intraclasts from dispersed volcanic particles in soils. Therefore, in terms of environmental geological dating, the tsunami came after the deposition over eastern Crete of airborne volcanic ash, but before the ash layer became dispersed by erosion and soil-biological mixing. A tsunami generated in the 3rd or 4th (last) eruption phase, as found on Thera, meets the above requirement and fits the presence of discrete volcanic ash in the tsunami deposits at Palaikastro (Bruins et al. 2008). 


\section{ARCHAEOLOGICAL DATING OF THE TSUNAMI DEPOSITS}

Archaeological excavations at the pivotal site of Akrotiri on Thera, covered by thick layers of tephra, showed unmistakably that the Minoan Santorini eruption occurred during the Late Cycladic IA and Late Minoan IA (LM IA) ceramic periods (Table 1), which are time parallel (Doumas 1983).

Archaeological dating of the Minoan Santorini eruption in eastern Crete became possible through discoveries of volcanic ash from the latter eruption in archaeological stratigraphic contexts. Soles and Davaras (1990) found discrete layers of volcanic Santorini ash in Late Minoan IA strata at the site of Mochlos. Subsequent findings of volcanic ash at Mochlos suggest that the eruption occurred at the end of the Late Minoan IA period (Soles et al. 1995). At Palaikastro, volcanic ash was also discovered in LM IA layers during several seasons of archaeological excavations (MacGillivray et al. 1991, 1998). A comprehensive archaeological review and analysis of Minoan Crete before and after the Santorini eruption was carried out by Driessen and Macdonald (1997). New ceramic finds during archaeological excavations in 1997 at Knossos were studied by Warren (2007) to attempt a more precise linkage between the relative chronology of Minoan Crete and the Thera eruption. Warren (2007:498) concluded that the eruption happened most likely very late in LM IA.

At Palaikastro, in field section 2 at the Promontory (Figure 2), the tsunami deposit exhibited (Figure 5) volcanic Santorini ash intraclasts and a painted LM IA pottery sherd in situ (Bruins et al. 2008: Figure 8). This ceramic sherd is characterized by a dark-on-light foliate scroll. Such pottery is also distinctive in archaeological strata affected by the tsunami with accompanying layers of redeposited, water-laid Santorini ash in several areas in the excavated part of Minoan Palaikastro (MacGillivray et al. 1992:136, Figure 15), situated about $300 \mathrm{~m}$ inland from the present coastline. The LM IA pottery is the youngest ceramic element found in such strata. Therefore, the archaeological dating of the tsunami deposits at Palaikastro in eastern Crete is Late Minoan IA.

\section{RADIOCARBON DATING OF THE TSUNAMI DEPOSITS}

Bones of domesticated animals were found in tsunami deposits at Palaikastro along the coast and also at the main excavation site more inland. Such bones are rather short-lived, from $<1$ to a few years old and well suited for ${ }^{14} \mathrm{C}$ dating. Though marine shells are more problematic for dating than terrestrial systems, we include the results obtained for the Patellidae shell (Bruins et al. 2008), shown in Figure 4. The samples were pretreated with standard procedures for the materials involved (Mook and Waterbolk 1985) at the Radiocarbon Laboratory of the University of Groningen (the Netherlands) and subsequently dated by accelerator mass spectrometry (AMS). Collagen was extracted from the animal bones and combusted to $\mathrm{CO}_{2}$. The carbonate of the purified marine shell was extracted by an acid bath to obtain $\mathrm{CO}_{2}$. Subsequently, the $\mathrm{CO}_{2}$ gas of each sample was used to prepare the graphite targets for the ion source of the AMS (van der Plicht et al. 2000; Aerts-Bijma et al. 2001).

Two imbricated cattle bones form the tsunami deposits in field section 1 (Figure 3) along the Promontory gave dates of $3310 \pm 35$ (GrA-30336) and $3390 \pm 35$ BP (GrA-30339). The average uncalibrated age of these bones is $3350 \pm 25 \mathrm{BP}$ (Bruins et al. 2008), which agrees very well indeed with the average ${ }^{14} \mathrm{C}$ date for the Santorini eruption, $3350 \pm 10 \mathrm{BP}$ (Bronk Ramsey et al. 2004), as measured on short-lived organic material from the volcanic destruction layer in the excavations at Akrotiri (Thera).

The Patellidae shell from field section 2 at the Promontory (Figures 2, 4), clearly embedded in situ in the sedimentary matrix of the tsunami deposit with an intraclast of volcanic Santorini ash (Figure 4), yielded a ${ }^{14} \mathrm{C}$ date of $3790 \pm 60 \mathrm{yr} \mathrm{BP}$ (GrA-21607) (Table 2). Since marine biological 
systems incorporate the variable carbon reservoir effect of seawater, shells are less suitable for accurate dating in comparison to atmospheric (terrestrial) biological systems. Nevertheless, deducting $400 \mathrm{yr}$ - the average marine carbon residence time-from the above shell date gives a result of $3390 \pm 60$ yr BP (Bruins et al. 2008), which overlaps with the above cattle bone dates and with the uncalibrated ${ }^{14} \mathrm{C}$ age of the Minoan Santorini eruption (Bronk Ramsey et al. 2004).

Here, we report the first ${ }^{14} \mathrm{C}$ dating results of animal bones from the main excavation site at Minoan Palaikastro, near Building 6 (Table 2), about $300 \mathrm{~m}$ inland from the Promontory (Figure 2). Archaeological excavations in 1994 at the east side of Building 6 revealed a large drain filled with waterlaid mud and volcanic Santorini ash, as reported by MacGillivray et al. (1998:241-2). A lower jaw bone (sheep or goat) and a tooth were found in these deposits (zembil 2878). The sedimentary nature of this flooding event was apparently caused by the same tsunami that caused the chaotic deposits with redeposited clasts of volcanic Santorini ash at the Promontory along the coastline. Indeed, it had been suggested previously that a particular type of damage to Building 2, discovered in earlier archaeological excavations, might be explained by a tsunami in the Late Minoan (LM) IA period (MacGillivray et al. 1987:150-1; Driessen and Macdonald 1997:90).

The lower jaw from a sheep or goat and a tooth were found at the contact between the volcanic tephra and the underlying clayey mud (zembil 2878). The jaw bone was dated in duplicate and both results are similar in statistical terms (within $1 \sigma$ ) as the average ${ }^{14} \mathrm{C}$ date of the Minoan Santorini eruption (3350 \pm 10 BP, Bronk Ramsey et al. 2004): $3325 \pm 40$ (GrA-28991) and $3345 \pm 40$ BP (GrA-29041). Also, the ${ }^{14} \mathrm{C}$ date of the tooth, $3385 \pm 40 \mathrm{BP}$ (GrA-29042), overlaps in statistical terms very well (within $1 \sigma$ ) with the eruption date. Therefore, we have now $3{ }^{14} \mathrm{C}$ dates of shortlived organic material (bones), in a secure stratigraphic context at the east side of Building 6 (MacGillivray et al. 1998:241-2), which are similar as the bone dates from the Promontory. All dates fit the uncalibrated ${ }^{14} \mathrm{C}$ age for the Santorini eruption.

\section{DISCUSSION AND CONCLUSIONS}

The geoarchaeological tsunami deposits in the coastal Minoan town of Palaikastro (Bruins et al. 2008) have been dated in 3 fundamentally different ways to the time of the Minoan Santorini eruption. Geological dating to the latter volcanic cataclysm was facilitated by the presence of volcanic Santorini ash in these deposits, as well as by diagnostic tsunami signatures (Bruins et al. 2008). Archaeological dating was possible through the presence of LM IA pottery sherds as the youngest ceramic element in these deposits. The Minoan Santorini eruption occurred during the Late Minoan IA (Table 1) material-cultural period (Doumas 1983; Soles and Davaras 1990; Soles et al. 1995). Radiocarbon dating of animal bones in the tsunami deposits at Palaikastro, from 2 locations $300 \mathrm{~m}$ apart (the Promontory and a large drain east of Building 6), gave similar results (Table 2), all overlapping with $3350 \pm 10$ BP (Bronk Ramsey et al. 2004), the average uncalibrated date of the Santorini eruption.

How do the relative archaeological and uncalibrated ${ }^{14} \mathrm{C}$ ages from the Palaikastro tsunami deposits, matching within their own respective dating system with the Santorini eruption, relate to each other in real time? We calibrated the ${ }^{14} \mathrm{C}$ dates into calendar years (Table 3), using the IntCal04 calibration curve (Reimer et al. 2004) and the OxCal calibration program v 3.10 (Bronk Ramsey 1995, 2001). Rather than calibrating each ${ }^{14} \mathrm{C}$ date separately, we calculated 2 weighted averages: (1) for the bone dates from the tsunami deposit at the Promontory; (2) for the bone dates from the large drain near Building 6 (Table 3). The stratigraphy at each spot allows for combining (Bronk Ramsey 1995, 2001) the individual dates, which results in a better temporal representation and a smaller standard deviation. 
The weighted average of the bone dates from the Promontory, $3350 \pm 25 \mathrm{yr}$ BP (Figure 6), is extraordinarily similar to the average uncalibrated date of the Santorini eruption at Akrotiri (Thera), $3350 \pm$ 10 BP (Bronk Ramsey et al. 2004). The $\chi^{2}$ test approves the combining of the 2 bone dates; $T=2.6$, which is below the 5\% confidence limit of 3.8 (Figure 6). The calibrated date is $(1 \sigma)$ 1683-1616 (68.2\%), (2 б) 1732-1715 (3.7\%), 1692-1603 (78.3\%), 1587-1533 (13.4\%) cal BCE (Figure 6).

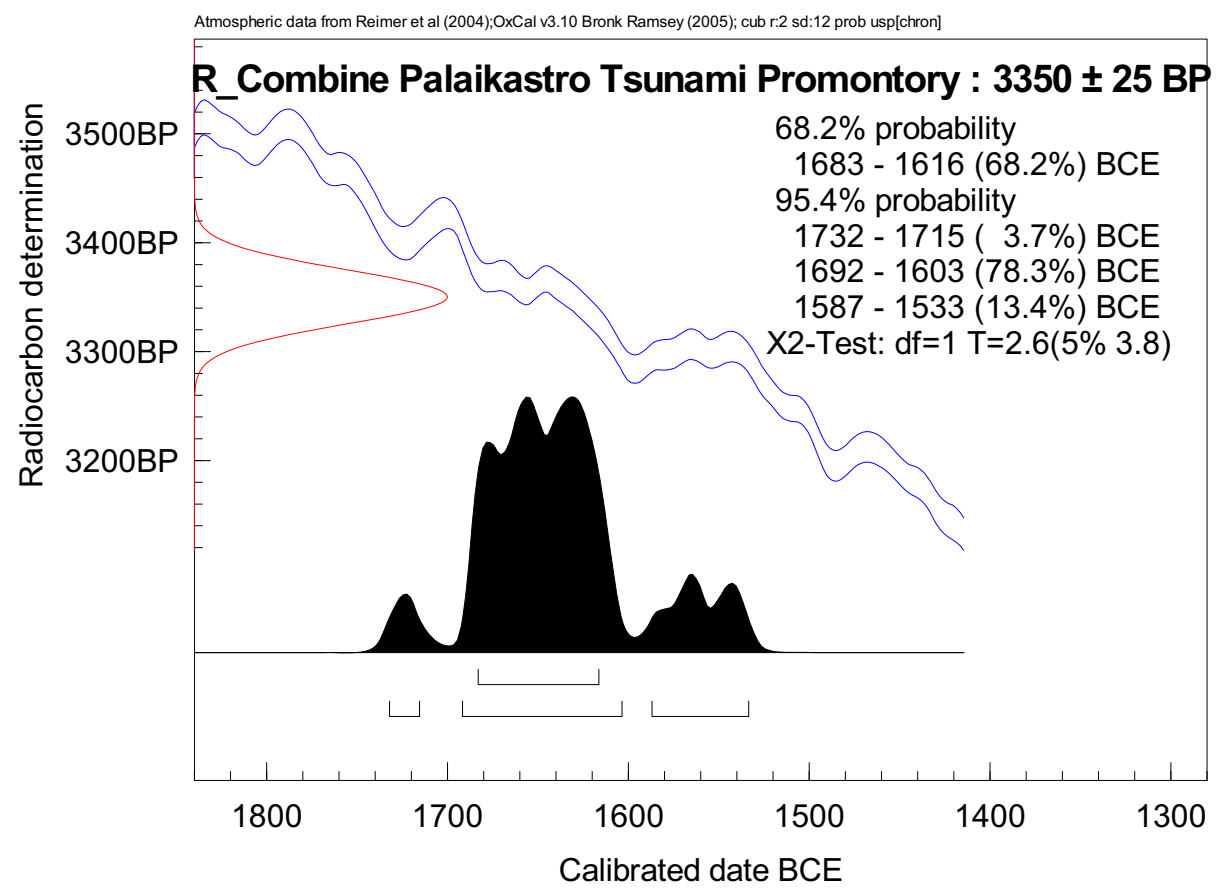

Figure 6 The weighted average of the 2 bone dates from the tsunami deposits at the Promontory (Figure 2, field section 1). The calibrated age range overlaps with the most accurate calibrated date for the Minoan Santorini eruption, 1627-1600 (95.4\%), established by wiggle-matching of tree-ring ${ }^{14} \mathrm{C}$ dates (Friedrich et al. 2006).

The weighted average of the bone dates from the water-laid redeposited volcanic Santorini ash and mud in the large drain east of Building 6 is $3352 \pm 23$ BP (Figure 7). This result is also amazingly similar to the average Santorini eruption date of $3350 \pm 10$ BP (Bronk Ramsey et al. 2004). The $\chi^{2}$ test underlines the high degree of coherence of the 3 bone dates; $T=1.2$, which is very low compared to the $5 \%$ confidence limit of 6.0 , above which $T$ should not rise (Figure 7 ). The calibrated

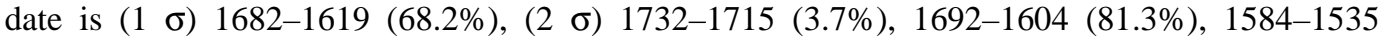
(10.4\%) cal BCE (Figure 7).

The site of Akrotiri at Thera (Santorini) obviously constitutes the pivotal basis for archaeological links with the volcanic cataclysm (Doumas 1983). The volcanic deposits "froze" the town of Akrotiri as it was at the time of the eruption and preserved it in a remarkable way. Many houses remained in a rather good shape, revealing extraordinary wall paintings, as well as remains of elegant furniture and other objects. Several thousand pottery vases were found virtually intact (Doumas 1983:108). Locally produced Late Cycladic IA ceramics dominate in the volcanic destruction layer, but also imported pottery is present. The Minoan cultural influence is apparent in the architecture, wall paintings, and ceramics (Doumas 1983:128). "Indeed, both imported Minoan pottery at Akrotiri, as well as local imitations, are restricted to the style prevailing in Late Minoan IA Crete; 


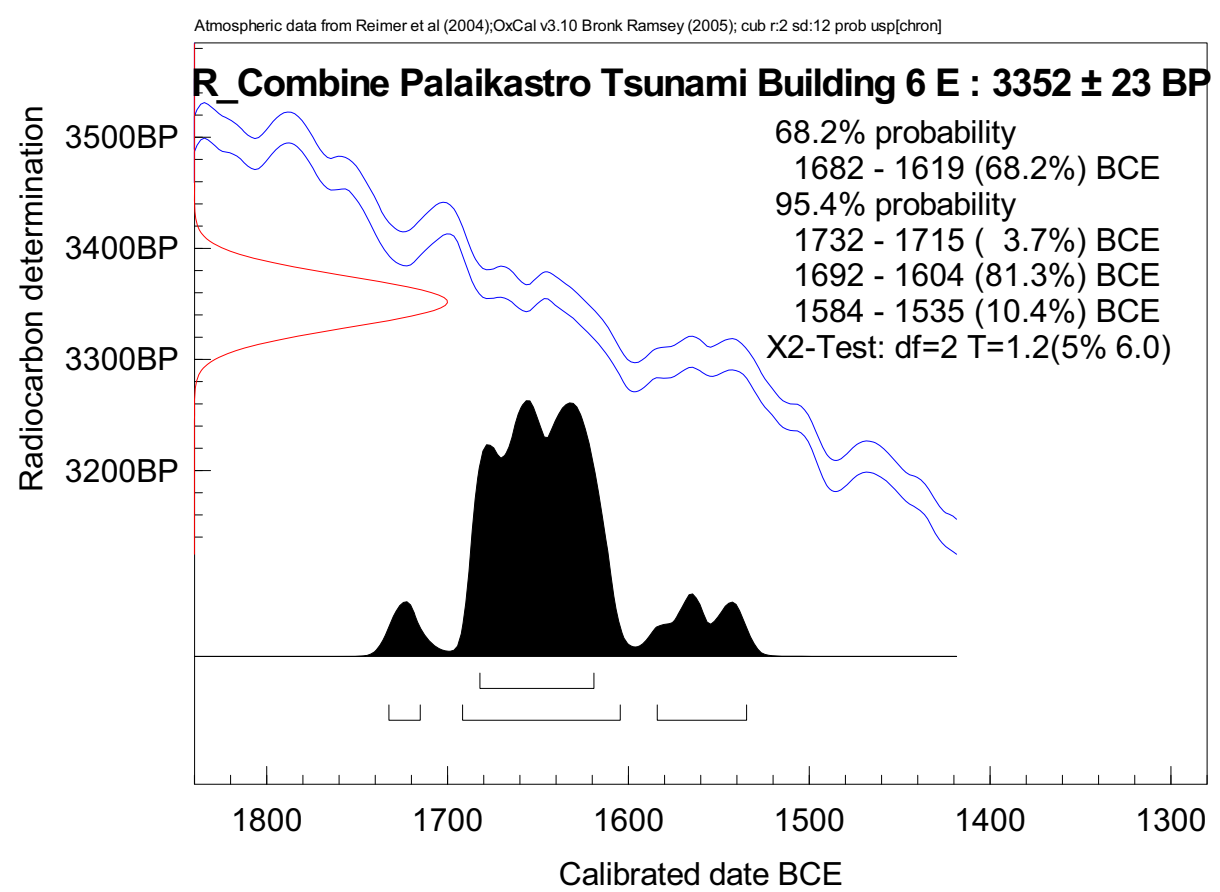

Figure 7 The weighted average of the 3 bone dates from the tsunami deposits east of Building 6 at the main excavation site (Figure 2). The calibrated age range overlaps with the most accurate calibrated date for the Minoan Santorini eruption, $1627-1600$ (95.4\%), established by wiggle-matching of tree-ring ${ }^{14} \mathrm{C}$ dates (Friedrich et al. 2006).

so far, pottery of the subsequent Late Minoan IB phase, the characteristic 'Marine Style,' is entirely absent. Having these two very distinctive and stratigraphically distinct styles as termini post and ante quem, the date of the end of Thera must be placed towards the end of the Late Minoan IA period in Crete, the absolute chronology of which is generally accepted to be c. 1500 BC.” (Doumas 1983: 139).

Here, we arrive at the crucial and controversial connection between Aegean archaeology and Egyptian historical chronology (Manning 1999; Bietak et al. 2001; Bietak 2003; Wiener 2003, 2007; Manning et al. 2006; Bietak and Höflmayer 2007). Most scholars (e.g. Warren and Hankey 1989; Driessen and Macdonald 1997; Wiener 2003, 2007; Bietak and Höflmayer 2007; Warren 2007) support a correlation that links the beginning of LM IA with the Second Intermediate or Hyksos period at around 1600 BCE (historical Egyptian chronology time) and the end of LM IA with the 18th Dynasty at $\sim 1480$ BCE (historical Egyptian chronology time); see also Table 1.

It is indeed striking that seaborne Santorini pumices in the excavations at Tell el-Dabca appear first in 18th Dynasty strata dated to the Thutmoside period, particularly in Phase C/2 (Bietak 2003; Bietak and Höflmayer 2007). The earliest pumice finds at the Palace District in cEzbet Helmi (Tell el-Daba), from Workshop N in Area H/I, may be related to the reign of Tuthmosis I around 1500 BCE (Bietak et al. 2001; Wiener 2007). The seaborne pumice from the Minoan Santorini eruption could have arrived earlier on the Egyptian Mediterranean shores, but it seems unlikely that it would have been left unnoticed and unused for a long time. No Minoan Santorini pumice has been found so far in Hyksos context at Tell el-Dabca (Bietak 2003). 
The most accurate calibrated ${ }^{14} \mathrm{C}$ date for the Minoan Santorini eruption (Friedrich et al. 2006) is based on ${ }^{14} \mathrm{C}$ dates of 72 tree rings in a branch with preserved outer bark of an olive tree at Santorini. The tree was buried alive by the massive tephra deposits of the eruption, according to its upright position. Using the OxCal program (Bronk Ramsey 1995, 2001), Friedrich et al. (2006) wigglematched the ${ }^{14} \mathrm{C}$ dates of the tree rings with the IntCal04 calibration curve (Reimer et al. 2004) to determine the calibrated age range of the outermost ring: 1621-1605 BCE (1 $\sigma)$ and 1627-1600 BCE $(2 \sigma)$.

Thus, we have a time difference of about 100-150 yr for the Minoan Santorini eruption between calibrated ${ }^{14} \mathrm{C}$ dating and archaeo-historical dating linked to Egyptian chronology. The geological, archaeo-historical, and ${ }^{14} \mathrm{C}$ dating of the Palaikastro tsunami deposits independently confirm this chronological difference (Table 3). ${ }^{14} \mathrm{C}$ dates from Tell el-Dabca in the eastern Nile Delta also show such a time discrepancy between ${ }^{14} \mathrm{C}$ dating and the historical Egyptian chronology for part of the 2nd millennium BCE. ${ }^{14} \mathrm{C}$ dates on charcoal from the Middle Bronze IIA and Middle Bronze I phases of Tell el-Dabca showed significantly older ages in most cases than the conventional historical chronology of Egypt (Bruins 2007), but the unknown old-wood effect of these charcoal dates may conveniently be blamed. However, the yet unpublished ${ }^{14} \mathrm{C}$ dates on short-lived organic material from Tell el-Dabca, measured by Walter Kutschera at the VERA Radiocarbon Laboratory (AMS) in Vienna, show calibrated results that are consistently older than the conventional historical chronology of Egypt by 100-150 yr (Bietak and Höflmayer 2007:14, Figure 1). The reasons for the discrepancy in the eastern Mediterranean region between ${ }^{14} \mathrm{C}$ dating and archaeo-historical dating during part of the 2nd millennium BCE have not yet been resolved.

Manning (1999) advocated changes in the conventional interregional archaeological correlations between Aegean and Egyptian archaeology in an attempt to solve the problem. For example, Manning (1999:339, Figure 62) relates the beginning of LM IA to Stratum E/1 at Tell el-Dabca, the Santorini eruption to Stratum D/3, and the end of LM IA to the end of Stratum D/3 or to Stratum D/2 at Tell el-Dabca. All these strata belong to the Hyksos period (Bietak 1997; Bietak and Höflmayer 2007).

We do not agree with these alternative material-cultural correlations as proposed by Manning (1999). If his suggestions were correct, then one would expect ${ }^{14} \mathrm{C}$ dates from Tell el-Dabca for these strata to comply with his scheme. However, this is not the case. For example, Stratum E/1 at Tell elDabca has a 2- $\sigma$ calibrated ${ }^{14} \mathrm{C}$ date, after sequencing, of approximately 1710-1770 BCE (visually estimated from Figure 1 of Bietak and Höflmayer 2007:14). Likewise, Stratum D/3, correlated by Manning with the Minoan Santorini eruption, has a 2- $\sigma$ calibrated ${ }^{14} \mathrm{C}$ date after sequencing of approximately 1680-1740 BCE (visually estimated from Figure 1 of Bietak and Höflmayer 2007: 14). This is roughly $50-140$ yr older than the most accurate calibrated date of the Santorini eruption, 1627-1600 BCE, according to Friedrich et al. (2006). Stratum D/2 has a 2- $\sigma$ calibrated ${ }^{14} \mathrm{C}$ date of approximately 1660-1730 BCE (visually estimated from Figure 1 of Bietak and Höflmayer 2007: 14). Therefore, the changes in interregional archaeological material-cultural correlations, as proposed by Manning (1999), are not supported on the time-basis of ${ }^{14} \mathrm{C}$ dating.

On the other hand, 2- $\sigma$ calibrated ${ }^{14} \mathrm{C}$ dates of the 18th Dynasty New Kingdom strata C3 and C2 at Tell el-Dabca overlap (visually estimated from Figure 1 of Bietak and Höflmayer 2007:14) with the Friedrich et al. (2006) date of 1627-1600 BCE (2 $\sigma$ ) for the Minoan Santorini eruption. These results underline the great value of using ${ }^{14} \mathrm{C}$ dating as a standard for comparison between different sites to sort out chronological and archaeological relationships (Bruins and Mook 1989; van der Plicht and Bruins 2001; Bruins and van der Plicht 2003). 
It can be concluded that the threefold dating of the tsunami deposits at Palaikastro (geological, archaeological, ${ }^{14} \mathrm{C}$ ) match, each within its own sphere, the timing of the Santorini eruption. ${ }^{14} \mathrm{C}$ dating appears to support grosso modo the conventional material-cultural archaeological correlations between the Aegean and Egypt. The Minoan Santorini eruption appears to have occurred during the 18th Dynasty, but more detailed future research is required to refine and substantiate these conclusions. Concerning the Egyptian historical chronology and the conventional material-cultural archaeological correlations, ${ }^{14} \mathrm{C}$ dating suggests that everything has to become older in parallel in calibrated ${ }^{14} \mathrm{C}$ years, thereby maintaining grosso modo the conventional interregional correlations.

However, our current understanding of historical Egyptian chronology (Kitchen 1996; Krauss and Hornung 2006; Bietak and Höflmayer 2007) does not seem to allow such a drastic rise in absolute years of about $100-150 \mathrm{yr}$, as suggested by calibrated ${ }^{14} \mathrm{C}$ years. Therefore, we advocate, for the time being, that a dual dating system be used in parallel: (1) archaeological dating linked through material-cultural correlations with Egyptian historical dates; (2) ${ }^{14} \mathrm{C}$ dating. Mixing dates of both systems in the problematic period(s) of the 2nd millennium BCE, for which a serious discrepancy exists between ${ }^{14} \mathrm{C}$ dating and historical Egyptian chronology, may lead to erroneous archaeological and historical correlations, as shown in the above examples. The duration of these problematic periods have yet to be investigated in detail. Finally, a "calibration curve" should be established between ${ }^{14} \mathrm{C}$ dating and Egyptian historical chronology. Such an effort may also assist to resolve the cause of the problem(s) between the 2 dating systems.

\section{ACKNOWLEDGMENTS}

We thank the Director of Antiquities for Eastern Crete and the Greek Ministry of Culture for their permission and support of the Palaikastro Excavations by the British School at Athens. The research was partly funded by the Institute for Aegean Prehistory and the Stichting Midbar Foundation. We thank the 2 reviewers for their comments and critical remarks, which considerably improved the final text.

\section{REFERENCES}

Aerts-Bijma AT, van der Plicht J, Meijer HAJ. 2001. Automatic AMS sample combustion and $\mathrm{CO}_{2}$ collection. Radiocarbon 43(2A):293-8.

Betancourt PP, Goldberg P, Hope Simpson R, Vitaliano CJ. 1990. Excavations at Pseira: the evidence for the Theran eruption. In: Hardy DA, Renfrew AC, editors. Thera and the Aegean World III. Volume 3. London: The Thera Foundation. p 96-9.

Bietak M. 1997. Avaris, capital of the Hyksos kingdom: new results of excavations. In: Oren ED, editor. The Hyksos: New Historical and Archaeological Perspectives. Philadelphia: The University Museum, University of Pennsylvania. p 87-139.

Bietak M. 2003. Science versus archaeology: problems and consequences of high Aegean chronology. In: Bietak M, editor. The Synchronisation of Civilisations in the Eastern Mediterranean in the Second Millennium B.C.-II. Vienna: Austrian Academy of Sciences. p 23-33.

Bietak M, Höflmayer F. 2007. Introduction: high and low chronology. In: Bietak M, Czerny E, editors. The Synchronisation of Civilisations in the Eastern Mediter- ranean in the Second Millennium B.C.-III. Vienna: Austrian Academy of Sciences. p 13-23.

Bietak M, Dorner J, Jánosi P. 2001. Ausgrabungen in dem Palastbezirk von Avaris. Vorberichte Tell el$\mathrm{Dab}^{\mathrm{C}} \mathrm{a} /{ }^{\mathrm{C}}$ Ezbet Helmi 1993-2000. Ägypte und Levante 11:27-119.

Bronk Ramsey C. 1995. Radiocarbon calibration and analysis of stratigraphy: the OxCal program. Radiocarbon 37(2):425-30.

Bronk Ramsey C. 2001. Development of the radiocarbon calibration program. Radiocarbon 43(2A):355-63.

Bronk Ramsey C, Manning SW, Galimberti M. 2004. Dating the volcanic eruption at Thera. Radiocarbon 46(1):325-44.

Bruins HJ. 2007. Charcoal radiocarbon dates of Tell elDaba. In: Bietak M, Czerny E, editors. The Synchronisation of Civilisations in the Eastern Mediterranean in the Second Millennium B.C.-III. Vienna: Austrian Academy of Sciences. p 65-77.

Bruins HJ, Mook WG. 1989. The need for a calibrated radiocarbon chronology of Near Eastern archaeology. Radiocarbon 31(3):1019-29. 
Bruins HJ, van der Plicht J. 2003. Assorting and synchronising archaeological and geological strata with radiocarbon: the Southern Levant in relation to Egypt and Thera. In: Bietak M, editor. The Synchronisation of Civilisations in the Eastern Mediterranean in the Second Millennium B.C.-II. Vienna: Austrian Academy of Sciences. p 35-42.

Bruins HJ, MacGillivray JA, Synolakis CE, Benjamini C, Keller J, Kisch HJ, Klügel A, van der Plicht J. 2008. Geoarchaeological tsunami deposits at Palaikastro (Crete) and the Late Minoan IA eruption of Santorini. Journal of Archaeological Science 35(1):191-212.

Dominey-Howes DTM. 2004. A re-analysis of the Late Bronze Age eruption and tsunami of Santorini, Greece, and the implications for the volcano-tsunami hazard. Journal of Volcanology and Geothermal Research 130(1-2):107-32.

Doumas CG. 1983. Thera: Pompeii of the Ancient Aegean. London: Thames and Hudson.

Doumas C, Papazoglou L. 1980. Santorini tephra from Rhodes. Nature 287(5780):322-4.

Driessen J, Macdonald CF. 1997. The Troubled Island, Minoan Crete Before and After the Santorini Eruption. Aegaeum 17. Université de Liège, Liège and University of Texas, Austin.

Druitt TH, Edwards L, Mellors RM, Pyle DM, Sparks RSJ, Lanphere M, Davies M, Barreiro B. 1999. Santorini Volcano. London: Geological Society, Special Memoir 19.

Friedrich WL. 2000. Fire in the Sea: The Santorini Volcano. Cambridge: Cambridge University Press.

Friedrich WL, Kromer B, Friedrich M, Heinemeier J, Pfeiffer T, Talamo S. 2006. Santorini eruption radiocarbon dated to $1627-1600$ B.C. Science 312(5773): 548.

Keller J. 1980. Prehistoric pumice tephra on Aegean islands. In: Doumas C, editor. Thera and the Aegean World, Volume II. London: The Thera Foundation. p 49-56.

Kitchen KA. 1987. The basics of Egyptian Chronology in relation to the Bronze Age. In: Åstrom P, editor. High, Middle or Low. Acts of an International Colloquium in Absolute Chronology. Göteborg: Åstroms. p 37-55.

Kitchen KA. 1996. The historical chronology of ancient Egypt: a current assessment. Acta Archaeologica 67: $1-18$.

Krauss R, Hornung E. 2006. Ancient Egyptian Chronology. Leiden: Brill.

MacGillivray JA, Sackett LH, Driessen J, Smyth D. 1987. Excavations at Palaikastro 1986. The Annual of the British School of Archaeology at Athens 82:13554, Plates 19-24.

MacGillivray JA, Sackett LH, Driessen J, Smyth D. 1991. Excavations at Palaikastro 1990. The Annual of the British School of Archaeology at Athens 86:12147, Plates 6-16.

MacGillivray JA, Sackett LH, Driessen J, Farnoux A, Smyth D. 1992. Excavations at Palaikastro 1991. The
Annual of the British School of Archaeology at Athens 87:121-52, Plates 3-7.

MacGillivray JA, Sackett LH, Driessen J, Hemingway S. 1998. Excavations at Palaikastro 1994 and 1996. The Annual of the British School of Archaeology at Athens 93:221-68, Plates 38-50.

Manning SW. 1999. A Test of Time-The Volcano of Thera and the Chronology and History of the Aegean and East Mediterranean in the Mid Second Millennium BC. Oxford: Oxbow Books.

Manning SW, Bronk Ramsey C, Kutschera W, Higham T, Kromer B, Steier P, Wild EM. 2006. Chronology for the Aegean Late Bronze Age 1700-1400 B.C. Science 312(5773):565-9.

Marinatos S. 1939. The volcanic destruction of Minoan Crete. Antiquity 13:425-39.

McCoy FW. 1980. The upper Thera (Minoan) ash in deep-sea sediments: distribution and comparison with other ash layers. In: Doumas C, editor. Thera and the Aegean World. Volume II. London: The Thera Foundation. p 49-56.

McCoy FW, Dunn S. 2002. Modelling the climatic effects of the LBA eruption of Thera: new calculations of tephra volumes may suggest a significantly larger eruption than previously reported (abstract). In: Proceedings of the Chapman Conference on Volcanism and the Earth's Atmosphere. American Geophysical Union, Santorini, Greece. p 21-2.

McCoy FW, Heiken G. 2000a. The Late Bronze Age explosive eruption of Thera (Santorini), Greece: regional and local effects. In: McCoy FW, Heiken G, editors. Volcanic Hazards and Disasters in Human Antiquity. Geological Society of America Special Paper 345. p 43-70.

McCoy FW, Heiken G. 2000b. Tsunami generated by the Late Bronze Age eruption of Thera (Santorini), Greece. Pure and Applied Geophysics 157(6-8): 1227-56.

Minoura K, Imamura F, Kuran U, Nakamura T, Papadopoulos GA, Takahashi T, Yalciner AC. 2000. Discovery of Minoan tsunami deposits. Geology 28(1): 59-62.

Mook WG, Waterbolk HT. 1985. Handbook for Archaeologists. No. 3. Radiocarbon Dating. Strasbourg: European Science Foundation.

Reimer PJ, Baillie MGL, Bard E, Bayliss A, Beck JW, Bertrand CJH, Blackwell PG, Buck CE, Burr GS, Cutler KB, Damon PE, Edwards RL, Fairbanks RG, Friedrich M, Guilderson TP, Hogg AG, Hughen KA, Kromer B, McCormac G, Manning S, Bronk Ramsey C, Reimer RW, Remmele S, Southon JR, Stuiver M, Talamo S, Taylor FW, van der Plicht J, Weyhenmeyer CE. 2004. IntCal04 terrestrial radiocarbon age calibration, 0-26 cal kyr BP. Radiocarbon 46(3):102958.

Sigurdsson H, Carey S. 1989. Plinian and co-ignimbrite tephra fall from the 1815 eruption of Tambora volcano. Bulletin of Volcanology 51(4):243-70. 
Sigurdsson H, Carey S, Alexandri M, Vougioukalakis G, Croff K, Roman C, Sakellariou D, Anagnostou C, Rousakis G, Ioakim C, Gogou A, Ballas D, Misaridis T, Nomikou P. 2006. Marine investigations of Greece's Santorini volcanic field. Eos, Transactions American Geophysical Union 87(34):337-48.

Soles JS, Davaras C. 1990. Theran ash in Minoan Crete: new excavations on Mochlos. In: Hardy DA, Renfrew AC, editors. Thera and the Aegean World III. Volume 3. London: The Thera Foundation. p 89-95.

Soles JS, Taylor SR, Vitaliano CJ. 1995. Tephra samples from Mochlos and their chronological implication for Neopalatial Crete. Archaeometry 37(2):385-93.

Thorarinsson S. 1978. Some comments on the Minoan eruption of Santorini. In: Doumas C, editor. Thera and the Aegean World I, Part One: Geosciences. London: Thera and the Aegean World. p 263-75.

van der Plicht J, Bruins HJ. 2001. Radiocarbon dating in Near-Eastern contexts: confusion and quality control. Radiocarbon 43(3):1155-66.

van der Plicht J, Wijma S, Aerts AT, Pertuisot MH, Meijer HAJ. 2000. The Groningen AMS facility: status report. Nuclear Instruments and Methods in Physics Research B 172(1-4):58-65.

Vitaliano CJ, Vitaliano DB. 1974. Volcanic tephra on Crete. American Journal of Archaeology 78:19-24.

Ward WA. 1992. The present status of Egyptian Chronol- ogy. Bulletin of the American Schools of Oriental Research 288:53-66.

Warren PM. 2007. A new pumice analysis from Knossos and the end of Late Minoan I A. In: Bietak M, Czerny $\mathrm{E}$, editors. The Synchronisation of Civilisations in the Eastern Mediterranean in the Second Millennium B.C.-III. Vienna: Austrian Academy of Sciences. p 495-9.

Warren PM, Hankey V. 1989. Aegean Bronze Age Chronology. Bristol: Bristol Classical Press.

Watkins ND, Sparks RSJ, Sigurdsson H, Huang TC, Federman A, Carey S, Ninkovich D. 1978. Volume and extent of the Minoan tephra from Santorini Volcano: new evidence from deep-sea sediment cores. Nature 271(5641):122-6.

Wiener MH. 2003. Time out: the current impasse in Bronze Age archaeological dating. In: Foster KP, Laffineur R, editors. METRON: Measuring the Aegean Bronze Age. Aegaeum 24. Université de Liège, Liège and University of Texas, Austin. p 363-99.

Wiener MH. 2007. Times change: the current state of the debate in Old World chronology. In: Bietak M, Czerny $\mathrm{E}$, editors. The Synchronisation of Civilisations in the Eastern Mediterranean in the Second Millennium B.C.-III. Vienna: Austrian Academy of Sciences. p 25-47. 